Article

\title{
Sustainable Business Strategies as an Element Influencing Diffusion on Innovative Solutions in the Field of Renewable Energy Sources
}

Ewa Stawicka (D)

Citation: Stawicka, E. Sustainable Business Strategies as an Element Influencing Diffusion on Innovative Solutions in the Field of Renewable Energy Sources. Energies 2021, 14, 5453. https://doi.org/10.3390/ en14175453

Academic Editors: Pierre Desrochers and Pablo del Río

Received: 8 June 2021

Accepted: 30 August 2021

Published: 1 September 2021

Publisher's Note: MDPI stays neutral with regard to jurisdictional claims in published maps and institutional affiliations.

Copyright: (C) 2021 by the author. Licensee MDPI, Basel, Switzerland. This article is an open access article distributed under the terms and conditions of the Creative Commons Attribution (CC BY) license (https:/ / creativecommons.org/licenses/by/ $4.0 /)$.
Management Institute, Warsaw University of Life Sciences (WULS), Nowoursynowska 166 St., 02-787 Warsaw, Poland; ewa_stawicka@sggw.edu.pl

\begin{abstract}
This article aims to examine the impact of corporate social responsibility, trust, and sustainable business strategies on the diffusion of innovative solutions in renewable energy sources. In this context, the material from the edition of the reports of the Polish Agency for Enterprise Development on innovation in the renewable energy industry was analyzed. A survey was also conducted among enterprises from the SME sector on the creation of a business model taking into account the diffusion of innovation in the field of renewable energy sources. The SME sector consists of entities that usually do not have an extensive organizational structure or research and development teams. Nevertheless, in the current economic situation, it is required that they are highly competitive, including through implemented innovations. Conscious participation of SME entities in the process of diffusion of innovation may be a solution that brings innovative solutions closer. The author stated that social responsibility had a moderate impact on the diffusion of innovation in the field of renewable energy in the SME sector, as it contributed the most to building trust in uncertain energy sources. On the other hand, the study conducted by the author showed that greater experience in the field of social responsibility (the company has a CSR department, there is a person responsible for CSR in the company, the company has a CSR policy, the company has a Code of Ethics, social reports are prepared in the company) had a positive relationship with building trust and commitment to innovative activities related to renewable energy sources. Conscious participation of SME entities in the process of diffusion of innovation may be a solution that approximates innovative solutions.
\end{abstract}

Keywords: sustainable business; innovation; trust

\section{Introduction}

Renewable energy is today one of the basic elements of sustainable development. One of the biggest problems of the modern economy is the depletion of traditional energy sources. It is also a very important topic for the European Union, therefore the development of renewable energy has become one of the priorities of the strategy [1]. As pointed out by S. Corsi, A.D. Minins [2], innovations in the energy sector will be ground-breaking innovations, i.e., innovations that will gradually displace the classic energy system from the market. Many innovative solutions in the field of renewable energy sources are still in the development phase or are not sufficiently developed. Innovative technologies using renewable energy sources are often too expensive, which makes them unattractive to potential recipients. High costs are undoubtedly limiting innovation in the energy sector. Nevertheless, it is worth looking for innovative solutions, because energy needs are growing and resources are shrinking. Renewable energy is obtained from natural processes, which replenishes its resources through natural, repeating cycles. It is an alternative to traditional energy sources, i.e., fossil fuels. Renewable energy includes energy from the direct use of solar radiation, wind, geothermal resources, water resources, solid biomass, biogas, and liquid biofuels. Therefore, the most important global issues, such as instabilities and water and climate change risks, need to be dealt with unanimously by 
all countries. Corporate social responsibility (CSR) is the main business initiative helping to deal with serious risk. Undoubtedly, corporate nature is the key factor determining corporate objectives, and the objective is the key factor determining corporate behaviors. Social responsibility, and above all the tools of corporate social responsibility (CSR), are effectively used to achieve sustainable development goals [3,4]. Taking socially responsible actions leads to mutual trust and, consequently, is a factor conducive to the creation of innovative products and processes [5]. CSR tools and strategies create new knowledge that must gain the trust of stakeholders. This new approach, in turn, influences the creation of specific business strategies towards sustainable development [6]. The article is an attempt to illustrate the approach to the diffusion of innovation in the field of renewable energy sources in the SME sector in Poland. The article attempts to define the relationship between corporate social responsibility and sustainable business strategy, as well as building trust in the company, and diffusion of innovation in the field of renewable energy. The article is organized as follows. The first part of the article briefly presents the motivation of this research and the purpose of this article. The second part contains a very brief theoretical background, CSR tools, and sustainable development as a business model, emphasizing the importance of trust, especially in the field of diffusion of innovation, i.e., in this case, renewable energy sources. In the third part, the authors present a description of the methods and data used. The next sections are the results of the study. The article ends with a discussion, final remarks, and research limitations.

\section{Literature Review}

\subsection{Social Responsibility}

The CSR model, which aims to balance the conflicting interests of stakeholders, assigns a completely different role to the management team, rather than the traditional and ambiguous one. Managers consciously decide on the distribution of benefits among competing stakeholder groups, i.e., customers, employees, suppliers, local community, and owners [7]. The implementation and application of the principles consistent with the CSR philosophy by enterprises may bring them tangible benefits relating to the improvement of the company's image and contribute to achieving better financial results due to greater customer trust. In practice, the problem is the difficulties resulting from measuring the results of CSR [8]. Methods for measuring CSR have occurred over time as expert assessments, indicators, management surveys, reputation indices, analysis of corporate publications, individual and organizational CSR measurement scales, indicators, standards or certificates, etc. CSR activities are voluntary and promote a dialogue and exchange of experiences in the field of good practices among stakeholders $[9,10]$. The essence of CSR is to have a strategy and, above all, to implement it in practice. The importance of how a company pays attention to CSR can be seen from organizational solutions, such as the existence of a position or department whose main scope is implementing CSR principles. The presence of a separately responsible business position or a designated person whose scope of duties covers the CSR policy is closely related to the advanced level in implementing the strategy. To protect their reputation, many companies develop and publish codes of conduct to define values and principles of conduct. The code of ethics is a document that defines the standards of behavior in an organization. Enterprises that implement ethical programs ensure a broader approach with the identification of the company's value, formulation of the mission, definition of ethical standards, development of a code of ethics, development of professional standards manual, development of an ethics education program, creation of a CSR position (unit), and constant monitoring of compliance with standards. Enterprises wanting to meet the expectations of stakeholders implement standardized CSR standards and submit them to a social audit. The ethics program aims to make business ethics the highest standard in a strategic company, and avoids reducing it to organizational activities. Furthermore, non-financial and social reporting is a tool of effective management. Social reports answer how enterprises contribute to improving conditions, processes, economic, social, and environmental trends at local, regional, and global levels. These tools engage 
stakeholders and encourage dialogue. Rational expectations of stakeholders should constitute the main point of reference for decisions made when building a CSR strategy and determining the company's priorities in the field of sustainable development. CSR is the best indicator for the commercial morals of an owner or manager of corporation. It deserves to be noted that more than half of the corporations in the world disclosed their CSR-related information in their annual financial reports. CSR is a strategic and profitable response to entry, in the long term [11,12]. The mission should not boil down to an abstract management tool for small and medium enterprises, used mainly by large companies. The SME's resources are very limited, which is an important obstacle hampering the development of social responsibility in the sector.

\subsection{Sustainable Business Strategy}

Sustainable development (SD) approaches differ between countries, regions, and organizations, but for all of them achieving a balance between output and input within the natural environment is a priority. Thus, SD is based on the ability to use renewable resources, reduce pollution and avoid reduction in nonrenewable assets [13,14]. Solving environmental problems related to climate change or implementing a circular economy are challenges that are associated with responsibility, trust, and innovation. Contemporary management directions, derived from the theory and practice of business, show the power of using their respective philosophies, concepts, and methods in enterprises' the modern conduct of the business activity. Organizations looking for optimal business models for sustainable growth and development take up strategic challenges based on sustainable development and business assumptions. The way of doing business is radically different now and in the era of unlimited access to information and knowledge, and there is a great possibility and speed of verification of the image and reputation of the company on the market. Hence, the concept of corporate social responsibility, which can be used to build long-term enterprise value, is becoming more and more critical. However, many companies relying on corporate social responsibility supported by the international community implement the assumptions of building a competitive position, taking into account the wishes of all stakeholders, paying attention to the importance of environmental issues. The starting point for the implementation of such a view on building a competitive position is the concept of sustainable development. Sustainable development is, therefore, characterized by three features: sustainability, and self-sustainability of development. Sustainability means the need to maintain the right proportions, the structure of development, and keeping a balance between development needs and the need to protect the environment. According to the UN, the following are very important to the creation of a balanced model of nations functioning: economic growth and even distribution of benefits, protection of natural resources and the environment, and social development [15]. Such an understanding of the business model allows for a change in strategic thinking by building a competitive advantage. This strategy requires the preservation of well-kept assets, the constant introduction of innovative products and services, and a good reputation among customers. Designing an effective and efficient strategic management system aimed at increasing the company's value is one of the priority activities of a modernly managed enterprise. Sustainable organizations demonstrate successful long-term performance aimed at the restricting economic, social, and environmental systems that are imposed by developing a strategy that sustainably generates and captures value into the future [11]. These sustainability [12] or sustainable [13] strategies are focused on the internal conditions of processes and compliance with external conditions (frame) formulated by government environmental management and SDGs implementation. "A green strategy implies a proclivity to collaborate with stakeholders concerning environmental improvements, share information with competitors concerning environmental improvements, emphasize environmental improvements rather than short-term economic gains, and emphasize environmental improvements as a means of increasing earnings" [13-15]. 


\subsection{Trust}

Trust plays a very important role in private and organizational life. In the literature on trust, one can find multidimensionality and interdisciplinary character. Trust in management and relationships with stakeholders gains in importance. Trust facilitates risk-taking, the effective use of resources, and influences the activities in the organization. Trust plays a huge role in innovative enterprises [16]. On the other hand, a low level of trust encourages you to hide information, reject new ideas, and even weaken the motivation and energy in the organization. Lack of trust negatively affects the mental health of employees and also reduces the performance of the organization. Trust cannot be forced on anyone and is built up gradually, but it can be quickly lost. Many studies show the need to build an organizational culture based on trust. To build trust that supports innovation, an appropriate company policy is needed to support creative people. Research shows a relationship between trust and innovation [17]. According to C. Williams et al. [18], knowledge transfer and knowledge creation require trust, and this, in turn, leads to innovation. Trust has a significant impact on innovation by creating an organizational climate. Nowadays, when organizations operate in a changing environment, trust takes on a new meaning. Building trust in businesses can result in success. Certainly, trust is a factor shaping stakeholder satisfaction and a motive for engagement. Confidence in innovation encourages faster implementation and use of it. Additionally, in the field of renewable energy sources, the circular economy, and megatrends, the question of trust in new solutions returns. The change in stakeholder attitudes becomes essential. This process can be supported by building awareness and trust. CSR/sustainability reports are also important in building stakeholder trust in companies. In these reports, companies present information about their non-financial results, including the use of energy from renewable sources very often. Informing stakeholders about the green strategy means a tendency to collaborate with stakeholders to improve the environment, share information on environmental improvement, emphasize environmental improvement rather than short-term economic benefits, and highlight environmental progress as a way to do to increase earnings. It should be emphasized that, in the long term, there is a risk of using CSR programs as a greenwashing or window decoration strategy, which affects the lack of trust and loss of trust in enterprises $[19,20]$. The firm that anticipates the environmentally-sound technology gains consumers that are willing to pay a higher price for their products, while companies are motivated to undertake CSR by adopting eco-R\&D [21]. Trust is closely associated with responsible activity.

\subsection{Innovation in the Field of Renewable Energy Sources}

The renewable energy sector is strategic for each country. The opening of energy markets has created an opportunity for new companies and the emergence of new business models based on technology, markets, and regulations. The growing interest in renewable energy became apparent in the early 1990s in many countries, including Poland. However, for a long time, the development of this sector in our country took place without state aid, almost exclusively as a result of bottom-up initiatives undertaken by investors, with the support of a few non-governmental institutions, and, at a later stage, local governments. One of the first factors stimulating the development of renewable energy in Poland was the implementation of international obligations under the Kyoto Protocol. Poland has committed to reducing greenhouse gases by $6 \%$ compared to 1989 [22]. The challenge is to create a financial support mechanism to change investment patterns shifting away from carbon dioxide emitting technologies to an investment pattern favoring investment in carbon-free renewable technologies. This ecological trend requires a new approach to risk management and new forms of capital. Proper management of intellectual property and protection of know-how is also of key importance. In the knowledge-based economy, innovations are the source of the competitive advantage of enterprises. Innovative knowledge allows you to act according to the rules that allow you to distance yourself from the competition. In the economy, the increase in added value is the result of not only productive work but also 
intellectual work. The new economy is the effect of structural changes that have taken place in economic activity due to the implementation of modern technologies. In Poland, the number of companies using innovative technologies that enable obtaining energy from renewable sources increases every year. The most popular technology for obtaining energy among Polish investors is a relatively cheap but also ecological installation powered by a biomass boiler. Furthermore, micro biogas plants are an opportunity for renewable energy sources. Agricultural biogas plants together with biomass boilers are the most stable energy sources for rural areas. Another popular form is solar collectors, i.e., those who convert solar radiation energy into thermal energy. The solar collector is an essential part of the domestic hot water heating system or supporting space heating in the building. Photovoltaics (PV), electricity coming from the sun, is gaining in importance. Undoubtedly, this source of energy has great potential, mainly due to the possibility of achieving various benefits both in the energy sector and in other sectors. Due to the problems of energy production in Poland in winter, in order to prevent energy shortages, batteries of adequate capacity should be added to the installation or they should be connected to the grid, which will balance the electricity supply. Another possibility is wind energy. Using this source of energy is becoming an important way of producing electricity. A wind farm consists of a rotor and a generator that generates electricity from kinetic energy. The degree of use of the installed wind power, and, thus, the profitability of the investment, depends on the local windiness of the area. Hydropower is also an opportunity but, at the same time, a technological challenge. The low cost of generating energy, however, is associated with the high cost of building a hydropower plant. Progressing climate change and more frequent droughts should be a signal for the construction of small hydropower plants. Innovative information and communication techniques guarantee correct communication between all entities generating energy on the market to use the available resources most efficiently [22,23]. RES-related projects are part of the concept of sustainable, self-sustaining dynamic development of the economy. The generated benefits prove the symbiosis of renewable energy sources with the natural environment and stimulate the improvement of the consumer's welfare. The benefits of renewable energy are in technological and economic as well as social and environmental terms. The future of not only Polish but global energy is related to renewable energy sources. This is reflected not only in the situation related to the depletion of the fossil fuel deposits exploited for several years, but also in the growing social awareness of the harmfulness of the use of conventional fuels. The RES technology is supported by the low cost of obtaining energy, relatively short construction time, energy security, and the possibility of building a self-sufficient energy economy in the face of not having such important raw materials as crude oil or natural gas today [24,25]. The relationship between innovation and CSR and their relationship may be two-way [26,27]. Market changes require its products, services, processes, and business models with failed innovations, responsibility for sustainable development [28]. Innovation-related strategies with an emphasis on tools to activate the interaction between economic, ecological, and social value operations [29,30]. Additionally, there are only a few studies on corporate social responsibility and CSR reporting practices of energy companies in several countries: Brazil [31,32], Poland [33], the US [34,35], China [36,37], India, and Japan [38], as well as in some other countries [39-42]. However, most of those studies do not provide a clear understanding of linkages between corporate social responsibility and its implications for sustainable energy development [3].

\section{Materials and Methods}

This study examines the relationship between a practical approach to corporate social responsibility, planning a sustainable development strategy, the value of trust, and an approach to innovation in renewable energy sources. Snowball-type assessment and sampling techniques were used to collect the data. The survey was conducted from September 2019 to July 2020. Using Google Forms, the author prepared an electronic version of the survey. The target group for the study was entrepreneurs from the SME 
sector, and Poland was the place of the draw. Ultimately, 147 enterprises operating in the agribusiness sector participated in the presented article. The distribution of the sample is presented in Table 1. There were no other inclusion or exclusion criteria for sampling. Each of the respondents completed the questionnaire independently. Efforts were made to collect as much data and responses as possible. The survey was conducted on enterprises from the SME sector to examine their attitude to CSR, SD, trust, and innovation in the field of renewable energy sources. The study used the convenient sampling method because the population consisted of homogeneous units. To test the research model, the following hypotheses were developed:

H1a. There is a significant and positive relationship between corporate social responsibility and a sustainable business strategy.

H1b. There is a significant and positive relationship between a sustainable corporate business strategy and the creation of trust.

H2. There is a significant and positive relationship between social responsibility and trust.

H3. There is a significant and positive relationship between trust and innovation in renewable energy sources.

H4. There is a significant and positive relationship between social responsibility and renewable energy innovation.

Table 1. Characteristics of the enterprises surveyed $(n=147)$.

\begin{tabular}{ccc}
\hline The Questionnaire Elements & Volume & Participation in \% \\
\hline Small (10-49 employees) & 52 & 35 \\
Medium (50-249 employees) & 67 & 46 \\
Large (over 250 employees) & 27 & 19 \\
\hline
\end{tabular}

Source: Own elaboration.

The scale expressions used in the inquiry form have been developed based on various studies. The practical approach to social responsibility was assessed based on the report on monitoring the social responsibility of the largest Polish companies [43]. The threepart group of statements was adapted from the study by A. Sankowska [17], C. Williams, and J. Du [18] trust measurement. The expectations related to the development of the sustainable business model strategy, consisting of six statements, were developed based on A. Jabłoński [44] and A. Jabłoński et al. [45]. Finally, judgments on the opinions and approach in enterprises to innovation in the field of renewable energy using a scale consisting of four questions based on M. Bajor [46].

Small and medium enterprises naturally aim their operations at achieving profit, which is the foundation of their very existence. However, under the mission's requirements, they should not act for profit only, and should meet broader social needs in the public interest too. Enterprises from the SME agribusiness sector involved in the processing of agricultural raw materials and the food industry as well as the production of means of production for agriculture and the food industry participated in the study. It is emphasized that these agribusiness departments should make a decisive effort to implement innovative solutions in renewable energy sources. The respondents' task was to evaluate each statement (Table 2-items) relating to the phenomenon in the analyzed organization on a five-point Likert scale (from 1-strongly disagree to 5-strongly agree). 
Table 2. Measurement model results.

\begin{tabular}{|c|c|c|c|c|c|c|}
\hline Variables & Items & Factor Loading & $T$-Value & CR & AVE & $\alpha$ \\
\hline \multirow{6}{*}{$\begin{array}{c}\text { Sustainable } \\
\text { business strategy }\end{array}$} & $\begin{array}{l}\text { The company appreciates the } \\
\text { importance of the process of economic } \\
\text { changes towards sustainable } \\
\text { development }\end{array}$ & 0.87 & 17.53 & \multirow{6}{*}{0.912} & \multirow{6}{*}{0.722} & \multirow{6}{*}{0.890} \\
\hline & $\begin{array}{l}\text { The company appreciates the } \\
\text { importance of the process of social } \\
\text { changes towards sustainable } \\
\text { development }\end{array}$ & 0.89 & 18.16 & & & \\
\hline & $\begin{array}{l}\text { The company appreciates the } \\
\text { importance of the process of ecological } \\
\text { changes towards sustainable } \\
\text { development }\end{array}$ & 0.89 & 18.16 & & & \\
\hline & $\begin{array}{l}\text { The company } \\
\text { appreciates the } \\
\text { importance of the } \\
\text { process of change } \\
\text { stowards a closed-loop }\end{array}$ & 0.74 & 10.59 & & & \\
\hline & $\begin{array}{l}\text { The company seeks and closes the } \\
\text { gaps in the area of sustainable } \\
\text { development based on ratio analyzes }\end{array}$ & 0.86 & 17.04 & & & \\
\hline & $\begin{array}{c}\text { The company's awareness } \\
\text { of sustainable } \\
\text { development is improving }\end{array}$ & 0.75 & 13.84 & & & \\
\hline \multirow{5}{*}{$\begin{array}{l}\text { Social } \\
\text { responsibility }\end{array}$} & $\begin{array}{l}\text { The company has a CSR department } \\
\text { on the website }\end{array}$ & 0.74 & 10.22 & \multirow{5}{*}{0.848} & \multirow{5}{*}{0.529} & \multirow{5}{*}{0.707} \\
\hline & $\begin{array}{l}\text { There is a person responsible for CSR } \\
\text { in the company }\end{array}$ & 0.65 & 10.21 & & & \\
\hline & The company has a CSR policy & 0.75 & 13.26 & & & \\
\hline & $\begin{array}{l}\text { The company has a } \\
\text { code of ethics }\end{array}$ & 0.73 & 11.93 & & & \\
\hline & $\begin{array}{l}\text { Social reports are prepared } \\
\text { in the company }\end{array}$ & 0.76 & 12.05 & & & \\
\hline \multirow{3}{*}{ Trust } & $\begin{array}{l}\text { Trust positively influences the } \\
\text { creation of knowledge }\end{array}$ & 0.76 & 13.99 & \multirow{3}{*}{0.899} & \multirow{3}{*}{0.573} & \multirow{3}{*}{0.871} \\
\hline & Learning has a positive effect on trust & 0.83 & 15.94 & & & \\
\hline & $\begin{array}{l}\text { Trust positively influences } \\
\text { innovation }\end{array}$ & 0.77 & 14.25 & & & \\
\hline \multirow{4}{*}{$\begin{array}{l}\text { Approach to } \\
\text { Innovation in the } \\
\text { field of renewable } \\
\text { energy sources }\end{array}$} & $\begin{array}{l}\text { The company has a positive } \\
\text { approach to innovation in the field } \\
\text { of wind energy }\end{array}$ & 0.82 & 15.94 & \multirow{4}{*}{0.934} & \multirow{4}{*}{0.780} & \multirow{4}{*}{0.935} \\
\hline & $\begin{array}{l}\text { The company has a positive } \\
\text { approach to innovation in the field of } \\
\text { solar energy }\end{array}$ & 0.91 & 20.06 & & & \\
\hline & $\begin{array}{l}\text { The company has a positive } \\
\text { approach to innovation in the field } \\
\text { of hydropower }\end{array}$ & 0.91 & 19.16 & & & \\
\hline & $\begin{array}{c}\text { The company has a positive approach } \\
\text { to innovation in the field of } \\
\text { biomass }\end{array}$ & 0.89 & 18.23 & & & \\
\hline
\end{tabular}

Source: Own elaboration.

\section{Results}

The structural equation model was used to investigate causal relationships and to test the structural validity of the conceptual model. In this context, the confirmatory factor analysis (CFA) was first performed with the use of a covariance matrix with the LISREL program to determine the accuracy of the scales used in the research. The factor loadings for all scale expressions were calculated as suggested above $0.6[47,48]$ (Table 2). It turned out that only the expression belonging to the flow experience scale had a low factor weight 
and was excluded from the analysis. Fit indicators proposed by $[49,50]$ were used to assess the adequacy of the model. The fit of the model was found with acceptable values $(\chi 2 / \mathrm{df}=2.099, \mathrm{RMSEA}=0.065, \mathrm{GFI}=0.83, \mathrm{AGFI}=0.81, \mathrm{CFI}=0.97, \mathrm{NFI}=0.95)$.

Moreover, the $\mathrm{t}$-values for the standardized factor loadings of all items turned out to be significant $(p<0.001)$, and the reliability coefficients (Cronbach's $\alpha$ ) ranging from 0.71 to 0.91 together with the combined reliability coefficients (CR) exceeded the critical value of 0 , 7 [51,52]. Therefore, it can be said that the reliability of the building is at a satisfactory level. Finally, the mean-variance (AVE), which was sorted for validity convergence and exceeded the critical threshold of 0.5 , was observed to be considered sufficient [50]. Moreover, the validity of the construct obtained in the confirmatory factor analysis was supported by the item factor coefficients, the reliability of the construct and the derived mean coefficient of variance. According to the results of the discrimination analysis, which tests the structural accuracy of the scale fit, the extracted mean square roots of the variance (AVE) must be greater than the correlation coefficients of the structures [53]. The correlation matrix between the structures is presented in Table 3. The numbers in parentheses represent the square roots of $\mathrm{AVE}$, and the numbers below them represent the correlation coefficients. Therefore, it was observed that the number of correlations between the factors is smaller than the square roots of the AVE. Therefore, it should be understood that the validity of the distinction regarding structural fit is acceptable. Based on the available data, it can be concluded that all scale expressions used in the data collection process contribute to structural correctness. In addition, it is understood that the model can be accepted satisfactorily given the agreement of confirmatory factor analysis (CFA) values.

Table 3. Correlation coefficients among variables.

\begin{tabular}{ccccc}
\hline Structure & Trust & $\begin{array}{c}\text { Sustainable } \\
\text { Business } \\
\text { Strategy }\end{array}$ & $\begin{array}{c}\text { Social } \\
\text { Responsibility }\end{array}$ & Innovation \\
\hline Trust & 0.756 & & & \\
Sustainable business strategy & 0.493 & 0.789 & 0.727 & \\
Social responsibility & 0.258 & 0.257 & 0.318 & 0.883 \\
Innovation & 0.272 & 0.660 & \\
\hline
\end{tabular}

The numbers in parentheses are the square roots of the extracted mean variances (AVE). Other numbers represent correlations between structures.

After realizing that the measurement model showed a satisfactory level of fit, it became possible to test the structural model and elucidate the causal relationships. The goodness of fit values for the structural model are presented in Table 4.

Table 4. Model statistics against the theoretical model.

\begin{tabular}{ccc}
\hline Indexes & Research Model & Recommended Criteria \\
\hline$\chi^{2} / \mathrm{df}$ & 2.543 & $<3$ \\
GFI & 0.8 & $>0.9$ \\
AGFI & 0.77 & $>0.8$ \\
IFI & 0.96 & $>0.9$ \\
CFI & 0.96 & $>0.9$ \\
RMSEA & 0.077 & $<0.08$ \\
\hline
\end{tabular}

Source: Own elaboration.

Although the GFI and AGFI values were slightly below the recommended criteria, they were at the critical threshold of 0.80 [53]. Therefore, it can be concluded that the research model has an acceptable level of fit. The results of the hypothesis tests are shown in Figure 1. 


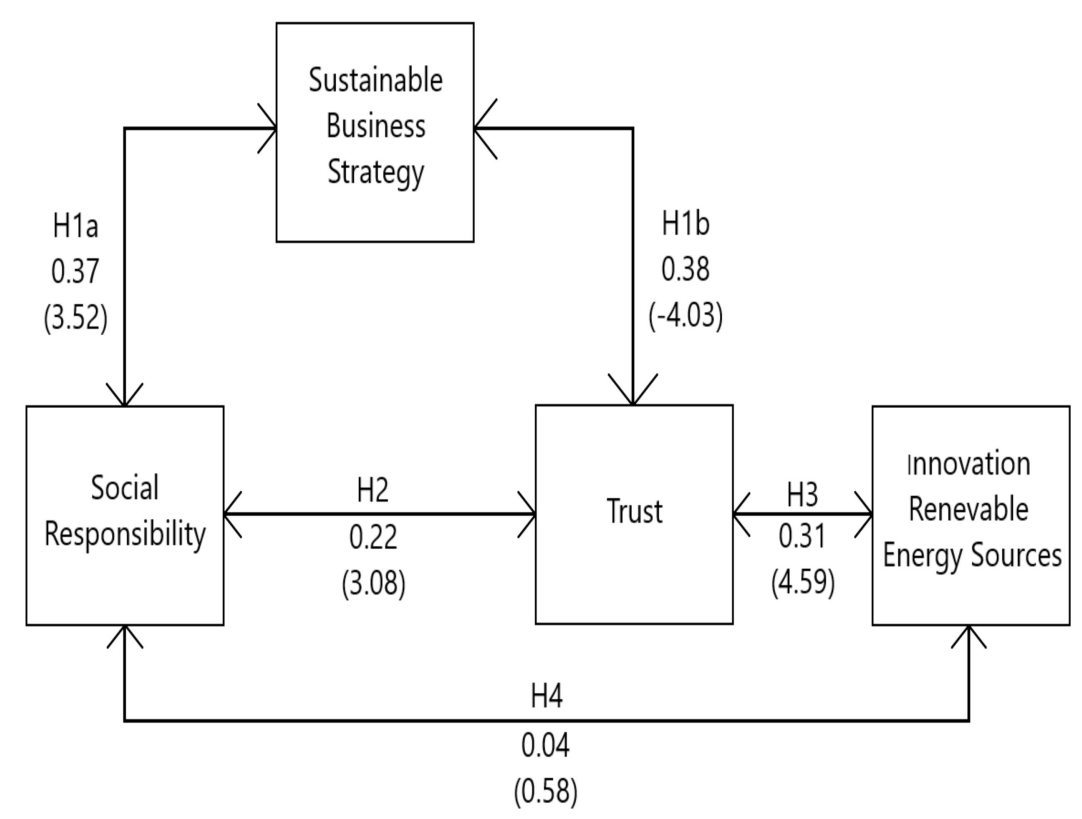

Figure 1. Analysis of the structural model and visualization of the result. Source: Own elaboration.

According to the results of structural equation modeling, it was found that the research model explains $60 \%$ of the total variance. According to the hypothesis test results, CSR positively influenced the sustainable business strategy $(\beta=0.37, p<0.05)$, while the sustainable business strategy positively influenced trust $(\beta=0.38, p<0.05)$. In light of this information, the $\mathrm{H} 1$ hypothesis, which assumes that H1(a) and CSR, H1(b) sustainable business strategies have a significant and positive relationship with trust, has been partially accepted. On the other hand, it can be seen that CSR has a significant and positive relationship with trust $(\beta=0.22, p<0.05)$. However, no significant influence of CSR on innovation was found $(\beta=0.04, p>0.05)$. Finally, it was understood that the influence of trust on innovation was significant and positive $(\beta=0.31, p<0.05)$. Based on these data, the hypotheses $\mathrm{H} 2$ and $\mathrm{H} 3$, which assume positive relations between CSR and trust and between trust and innovation, were confirmed, while hypothesis $\mathrm{H} 4$ explaining the role of CSR for innovation was not accepted. The results of the hypothesis test are summarized in Table 5.

Table 5. Verification and acceptance of hypotheses.

\begin{tabular}{cc}
\hline Hypothesis & $\begin{array}{c}\text { Hypothesis } \\
\text { Verification }\end{array}$ \\
\hline $\mathrm{H} 1 \mathrm{a}$ & accepted \\
$\mathrm{H} 1 \mathrm{~b}$ & accepted \\
$\mathrm{H} 2$ & accepted \\
$\mathrm{H} 3$ & accepted \\
$\mathrm{H} 4$ & rejected \\
\hline
\end{tabular}

Source: Own elaboration.

\section{Discussion}

The study aimed to build a research model that would examine the relationship between social responsibility manifested in possession of CSR tools, then consider building a sustainable development strategy in conjunction with confidence in innovation in renewable energy sources. Based on the findings, several theoretical contributions were discussed. First, the strength of the research model was clearly defined by finding: model reliability (i.e., the reliability of the index and internal consistency of all latent variables); establishing the validity of the model (i.e., convergent validity and discriminant validity of 
all latent variables); and evaluating the value of the dependent variables. This indicated that the model was strong enough to test the research hypotheses.

The concepts of modern enterprise management are based on the sustainability paradigm: corporate social responsibility (CSR) and sustainable development (SD). According to E. Skrzypek [54] and D. Teneta-Skiwiercz [55], excellent enterprises believe in the effectiveness of their operations. They are characterized by quick action, and concern the quality of products and services and implementation of innovations. CSR is a holistic concept encompassing economic, socio-cultural, and environmental responsibility. It is a kind of milestone on the way to sustainable development [56]. CSR is undoubtedly a concept that provides a space for creating innovations that, on the one hand, reduce the harmful impact of humans on the natural environment, positively affecting the quality of life of present and future generations, and on the other-bring benefits to enterprises themselves. A company using a CSR model based on a mutually beneficial strategy (reciprocal strategy) tries to find solutions in the event of a conflict between its economic goals and the pressure exerted by society. In this case, the basis for introducing responsible innovations is the assumption that CSR is a long-term investment that can bring benefits, not only to the local community but also to the enterprise itself. According to some researchers, both socially responsible practices stimulate innovation, as well as innovations, may affect CSR practices $[57,58]$. Not all researchers confirm the existence of a positive relationship between CSR and innovation. I. Gallego-Alvarez, J. Manuel Prado-Lorenzo, and I. GarciaSanchez [57] state that a negative correlation between CSR practices and innovations is also possible. This is because not all CSR projects create value for companies, as many of them increase costs. A higher quality of life translates into an increase in social awareness and requirements for the business sector, which favors the dissemination of the concept of corporate social responsibility. Moreover, a high level of economic development serves to create new social needs and causes society to demand better living conditions, innovative products, investments in the community, and protection of the natural environment. The literature on the subject often emphasizes the relationship between innovation and the implementation of the concept of CSR and sustainable development. On the other hand, K. Krot and D. Lewicka $[59,60]$ indicate the readiness and ability of an organization to implement innovations require the existence of any specific conditions. One of them is trust built on various levels of intra-organizational relationships. Therefore, it is important not only to determine the strength of the impact of organizational trust on innovation, but also to explain the mechanism of this impact. Thanks to trust, it is also possible to freely exchange information necessary for innovation to occur. In a situation of lack of trust, difficulties in mutual understanding arise and the costs of monitoring the exchange of knowledge, information, or measures to introduce innovation increase [61]. Innovations towards renewable energy sources are gaining importance. Today, renewable energy is one of the basic elements of sustainable development. One of the biggest problems of the modern economy is the depletion of traditional energy sources. Social responsibility in enterprises, and especially specific mechanisms, leads to creating a model of sustainable development based on the creation of new solutions in the social, ecological, and economic aspect. Innovations in the field of renewable energy sources fulfill these premises. It turns out, however, that new solutions should be combined with trust in all the segments analyzed above.

\section{Conclusions}

A research model was built to investigate social responsibility, a sustainable business model, and trust and attitudes to the implications for diffusion on innovation in renewable energy. The results of the study are in line with previous literature researching the impact of social responsibility on innovation and confidence in innovation, especially in new areas such as renewable energy sources. This article complements the general knowledge on the creation of CSR strategies and the diffusion of innovation in renewable energy sources and confidence in new solutions-also in the aspect of sustainable development. The author's 
research has shown a new aspect, confirmed by the results, that social responsibility is very important in enterprises from the SME sector because it indirectly influences the diffusion of innovations and is associated with trust in their creation and implementation. There is no direct link between CSR and diffusion of innovation in renewable energy sources, but only an indirect one. The survey defines CSR as the following: the company has a CSR department, the company has a person responsible for CSR, the company has a CSR policy, and reports are prepared in the company. Research has shown that these elements contributed to strengthening the competitive position and confidence in enterprises. A new approach is the need to make the CSR strategy more important in the SME sector.

The article complements the general knowledge on the creation of CSR strategies in connection with the diffusion of innovation in renewable energy sources and the confidence in the approach to new considerations. The research was conducted in enterprises from the SME sector. In most of the surveyed companies, the website included a CSR department, a CSR policy was implemented, a person was responsible for CSR, and codes of ethics and social reports were prepared less frequently.

Most of the surveyed entities appreciated the importance of the economic transformation process towards sustainable development and the need to improve the business model strategy towards sustainable development. It was also confirmed that trust positively influences the creation of new knowledge in enterprises. Learning positively influences the creation of trust, and trust positively influences the diffusion of innovation; in this case, the question was asked about the diffusion of innovation in the field of renewable energy sources. There has been a positive approach to diffusion of innovation in companies, especially in the field of solar energy.

The study showed that CSR activities had a positive impact on the creation of knowledge and strategies in the field of sustainable business. Having a sustainable business strategy has had a positive effect on creating trust.

Moreover, CSR has a significant and positive relationship with creating trust. An important element was building trust in the diffusion of innovation in renewable energy sources. Thus, there were positive relations between CSR and trust, and between trust and diffusion of innovation.

The study has limitations as it was conducted on a small group of enterprises only from the SME sector; a larger research sample could give better results. Another limitation is the selection of measures for the research tool as there was no standardization of the tool, thus it could be extended to other constructs in the future. Still, this study contributes to further research.

Funding: This research received no external funding.

Conflicts of Interest: The authors declare no conflict of interest.

\section{References}

1. Euractiv. Międzynarodowa Agencja Energetyczna. Available online: https://www.euractiv.pl/section/energia-i-srodowisko/ news / mea-energetyka-raport-2021-elektrycznosc-wegiel-paliwa-kopalne-ropa-gaz-hybrydy-transformacja-cop26-turowelektrownie-porozumienie-paryskie-klimat-niskoemisyjnosc/ (accessed on 30 May 2021).

2. Corsi, S.; Minin, A.D. Disruptive innovation in reverse: Adding a geographical dimension to disruptive innovation theory. Creat. Innov. Manag. 2014, 23, 76-90. [CrossRef]

3. Lu, J.; Ren, L.; Yao, S.; Qiao, J.; Strielkowski, W.; Streimikis, J. Comparative review of corporate social responsibility of energy utilities and sustainable energy development trends in the Baltic states. Energies 2019, 12, 3417. [CrossRef]

4. Mariani, M.M.; Buhalis, D.; Czakon, W.; Vitouladiti, O. Tourism management, marketing and development. In Performance, Strategies and Sustainability; Palgrave-Macmillan: New York, NY, USA, 2016.

5. Stawicka, E. Sustainable development in the digital age of entrepreneurship. Sustainability 2021, 13, 4429. [CrossRef]

6. Stawicka, E. Sustainable development and the business context of CSR benefits on the Polish market. Acta Sci. Pol. Oeconomia 2017, 16, 73-81. [CrossRef]

7. Svenson, G.; Wood, G.; Callaghan, M. A corporate model of sustainable business practices: An ethical perspective. J. World Bus. 2010, 45, 336-345. [CrossRef] 
8. Stawicka, E.; Paliszkiewicz, J. Social media in communicating about social and environmental issues-Non-financial reports in Poland. Information 2021, 12, 220. [CrossRef]

9. Stefănescu, C.A.; Tiron-Tudor, A.; Moise, E.M. EU non-financial reporting research-Insights, gaps, patterns and future agenda. J. Bus. Econ. Manag. 2021, 22, 257-276. [CrossRef]

10. Annas, G.J.; Beisel, C.L.; Clement, K.; Crisanti, A.; Francis, S.; Galardini, M.; Galizi, R.; Grünewald, J.; Immobile, G.; Khalil, A.S.; et al. A code of ethics for gene drive research. CRISPR J. 2021, 4, 19-24. [CrossRef] [PubMed]

11. Lloret, A. Modeling corporate sustainability strategy. J. Bus. Res. 2016, 69, 418-425. [CrossRef]

12. Farias, G.; Farias, C.; Krysa, I.; Harmon, J. Sustainability mindsets for strategic management: Lifting the yoke of the neo-classical economic perspective. Sustainability 2020, 12, 6977. [CrossRef]

13. Peters, J.; Simaens, A. Integrating sustainability into corporate strategy: A case study of the textile and clothing industry. Sustainability 2020, 12, 6125. [CrossRef]

14. Aarstad, J.; Jakobsen, S.-E. Norwegian firms' green and new industry strategies: A dual challenge. Sustainability 2020, $12,361$. [CrossRef]

15. Johannesburg Summit 2002. World Summit on Sustainable Development, UN. Available online: https://www.sabic.com/en/ collaboration/trend/sustainability?gclid=EAIaIQobChMI0OPRr9CC8QIVi7myCh05igd3EAAYAiAAEgKtZvD_BwE (accessed on 7 June 2021).

16. Paliszkiewicz, J. Przywództwo, Zaufanie, Zarzadzanie Wiedza w Innowacyjnych Przedsiebiorstwa [Leadership, Trust, Knowledge Management in Innovative Enterprises]; CeDEWu: Warszawa, Poland, 2019; pp. 1-215.

17. Sankowska, A. Relationship between organizational trust, knowledge transfer, knowledge creation and firm's innovativeness. Learn. Organ. 2013, 20, 85-100. [CrossRef]

18. Williams, C.; Du, J. The impact of trust and local learning on the innovative performance of MNE subsidiaries in China. Asia Pac. J. Manag. 2014, 31, 973-996. [CrossRef]

19. Shea, C.T.; Hawn, O.V. Microfoundations of corporate social responsibility and irresponsibility. Acad. Manag. J. 2019, 62, 1609-1642. [CrossRef]

20. Sulich, A.; Sołoducho-Pelc, L.M. Renewable energy producers' strategies in the Visegrád GroupCountries. Energies 2021, 14, 3048. [CrossRef]

21. Hong, L.; Chao, A. Strategic corporate social responsibility, sustainable growth, and energy policy in China. Energies 2018, 11, 3024. [CrossRef]

22. Skoczkowski, T.; Bielecki, S. Konieczność zapewnienia interesów odbiorców końcowych w procesie budowy inteligentnych sieci [The need to ensure the interests of end users in the process of building smart grids]. Przeglad Elektrotechniczny 2015, 1/2015, 90. [CrossRef]

23. Kucęba, R.; Bajor, M. Energetyka prosumencka w konwergencji ze zrównoważonym rozwojem [Prosumer energy in convergence with sustainable development]. In Energetyka Prosumencka. Pierwsza Próba Konsolidacji [Prosumer Energy. First Attempt at Console]; Popczyk, J., Kucęba, R., Dębowski, K., Jędrzejczyk, W., Eds.; Sekcja Wydawnictw Wydziału Zarządzania Politechniki Częstochowskiej: Częstochowa, Poland, 2014; p. 221.

24. Lewandowski, W.M. Proekologiczne Odnawialne Źródła Energii [Pro-Ecological Renewable Energy Sources]; Wydawnictwo WNT: Warszawa, Poland, 2012.

25. Paska, J.; Pawlak, K.; Surma, T. System wsparcia, jako istotny element optymalizacji wpływu nowych Ekologicznych źródeł energii elektrycznej na system elektroenergetyczny [The support system as an important element of optimizing the impact of new ecological sources of electricity on the power system]. Rynek Energii 2013, 2/13, 1-11.

26. Macgregot, S.P.; Fontodrona, J. Exploring the Fit Between CSR and Innovation. Available online: https://media.iese.edu/ research/pdfs/DI-0759-E.pdf (accessed on 30 May 2021).

27. Cordova, M.F.; Celone, A. SDGs and Innovation in the Business Context Literature Review. Sustainability 2019, 11, 7043. [CrossRef]

28. Kneipp, J.M.; Gomes, C.M.; Bichueti, R.S.; Frizzo, K.; Perlin, A.P. Sustainable innovation practices and their relationship with the performance of industrial companies. Revista de Gestão 2019, 26, 94-111. [CrossRef]

29. Hall, J.; Vredenburg, H. The challenges of innovating for sustainable development. MIT Sloan Manag. Rev. 2003, $45,61-68$.

30. Boons, F.; Montalvo, C.; Quist, J.; Wagner, M. Sustainable innovation, business models and economic performance: An over-view. J. Clean. Prod. 2013, 45, 1-8. [CrossRef]

31. Sartori, S.; Witjes, S.; Campos, L.M.S. Sustainability performance for Brazilian electricity power industry: An assessment integrating social, economic and environmental issues. Energy Policy 2017, 111, 41-51. [CrossRef]

32. Camargos, M.R.; Jannuzzi, G.M.; Gavira, M.O. Analysis of the sustainability reporting initiatives of electric utilities in Brazil. Industrija 2014, 42, 127-147. [CrossRef]

33. Szczepankiewicz, E.I.; Mucko, P. CSR Reporting Practices pf Polish Energy and Mining Companies. Sustainability 2016, 8, 126. [CrossRef]

34. Sidhoum, A.A.; Serra, T. Corporate social responsibility and dimensions of performance: An application to US electric utilities. Util. Policy 2017, 48, 1-11. [CrossRef]

35. Kraft, B. Shedding light on stakeholder power in a regulated market: A study of variation in electric utilities' climate change disclosures. Organ. Environ. 2017, 31, 314-338. [CrossRef] 
36. Chang, K. The efects of ownership and capital structure on environmental information disclosure: Empirical evidence from Chinese listed electric firms. WSEAS Trans. Syst. 2013, 12, 315-330.

37. Li, J.; Sun, X.; Li, G. Relationships among green brand, brand equity and firm performance: Empirical evidence from China. Transform. Bus. Econ. 2018, 17, 221-236.

38. Bahari, N.A.S.; Alrazi, B.; Husin, N.M. A comparative analysis of carbon reporting by electric generating companies in China, India, and Japan. Proc. Econ. Financ. 2016, 35, 74-81. [CrossRef]

39. Alrazi, B.; Villiers, C.D.; Staden, C.J.V. The environmental reporting of electric utilities: An international comparison. In Proceedings of the 9th CSEAR Australasian Conference, Albury-Wodonga, Australia, 5-7 December 2010.

40. Traxler, A.A.; Greiling, D. Sustainable public value reporting of electric utilities. Balt. J. Manag. 2018, 14, 103-121. [CrossRef]

41. Talbot, D.; Boiral, O. GHG reporting and impression management: An assessment of sustainability reports from the energy sector. J. Bus. Ethics 2015, 147, 367-383. [CrossRef]

42. Lopez-Valeiras, E.; Gomes-Conde, J.; Naranjo-Gil, D. Sustainable innovation, management accounting and control systems, and international performance. Sustainability 2015, 7, 3479-3492. [CrossRef]

43. Fundacja CENTRUMCSR.pl. Społeczna Odpowiedzialność Biznesu w Polskich Realiach: Teoria a Praktyka; Raport z moni-toringu społecznej odpowiedzialności największych polskich firm [Corporate social responsibility in the Polish reality: Theory and practice. Report on monitoring the social response of the largest Polish companies]; Printvit Sp. z o.o.: Warszawa, Poland, 2015; p. 90.

44. Jabłoński, A. A sustainable development and sustainable business in kreation of value the companies responsible socially. In Europejskie Forum Odpowiedzialności Ekologicznej; CERT Sp. z o.o.: Warszawa, Poland, 2010.

45. Jabłoński, A. Sustainable Business Models; MDPI: Basel, Switzerland, 2019.

46. Bajor, M. Innowacyjne metody pozyskiwania energii z odnawialnych źródeł energii [Innovative methods of obtaining energy from renewable energy sources]. Zeszyty Naukowe Politechniki Slaskiej. Seria: Organizacja i Zarzadzanie 2017, 114, 11-21.

47. Chen, C.F.; Tsai, D. How destination image and evaluative factors affect behavioral intentions? Tour. Manag. 2007, 28, 1115-1122. [CrossRef]

48. Kline, P. An Easy Guide to Factor Analysis, 1st ed.; Routledge: Oxfordshire, UK, 1994.

49. Jöreskog, K.G.; Sörbom, D. LISREL 8: Structural Equation Modeling with the SIMPLIS Command Language; Scientific Software International: Skokie, IL, USA, 1993.

50. Hair, J.T.; Anderson, R.E.; Tatham, R.L.; Black, W.C. Multivariate Data Analysis with Readings, 3rd ed.; Macmillan: New York, NY, USA, 1999.

51. Field, A. Discovering Statistics Using SPSS, 3rd ed.; Sage Publication: London, UK, 2011.

52. Fornell, C.; Larcker, D.F. Structural equation models with unobservable variables and measurement error: Algebra and statistics. J. Mark. Res. 1981, 19, 39-50. [CrossRef]

53. Kim, Y.J.; Han, J. Why smartphone advertising attracts customers: A model of web advertising, flow, and personalization. Comput. Hum. Behav. 2014, 35, 586. [CrossRef]

54. Skrzypek, E. Doskonalenie jakości jako szansa na sukces organizacji [Quality improvement as a chance for the success of the organization]. Wspótczesne Zarzadzanie 2010, 3, 1-9.

55. Teneta-Skwiercz, D. Innowacje społecznie odpowiedzialne jako narzędzie doskonalenia przedsiębiorstwa/Socially responsible innovations as a tool of the company improvement. Res. Pap. Wroc. Univ. Econ. 2016, 17, 320-336. [CrossRef]

56. Ketola, T. Five leaps to corporate sustainability through a corporate responsibility portfolio matrix. Corp. Soc. Responsib. Environ. Manag. 2010, 17, 320-336. [CrossRef]

57. Gallego-Alvarez, I.; Prado-Lorenzo, J.M.; Garcia-Sanchez, I.-M. Corporate social responsibility and innovation: A resource-based theory. Manag. Decis. 2011, 49, 1709-1727. [CrossRef]

58. Bacinello, E.; Tontini, G.; Alberton, A. Maturity in sustainable innovation and corporate social responsibility: Implications in business performance. Braz. J. Manag. 2019, 12, 749-759.

59. Krot, K.; Lewicka, D. Wpływ zaufania organizacyjnego na innowacyjność w świetle badania jakościowego [The impact of organizational trust on innovation in the light of qualitative research]. Studia i Prace Wydziału Nauk Ekonomicznych $i$ Zarzadzania $2015,39,3$.

60. Ellonen, R.; Blomqvist, K.; Puumalainen, K. The role of trust in organizational innovativeness. Eur. J. Innov. Manag. 2008, 11, 160-181. [CrossRef]

61. De Jong, G.; Woolthuis, K.R. The institutional arrangements of innovation: Antecedents and performance effects of trust in high-tech alliances. Ind. Innov. 2008, 15, 45-67. [CrossRef] 